\title{
Penyerapan Ion Aluminium dan Besi dalam Larutan Sodium Silikat Menggunakan Karbon aktif
}

\author{
Nurhasni $^{1}$, Florentinus Firdiyono ${ }^{2}$, Qosim Sya'ban ${ }^{3}$ \\ 1,3Program Studi Kimia FST UIN Syarif Hidayatullah Jakarta \\ 2Puslit Metalurgi-LIPI \\ e-mail: hasni_1806@yahoo.com
}

\begin{abstract}
Abstrak
Telah dilakukan penelitian terhadap kemampuan karbon aktif sebagai adsorben untuk menyerap ion $\mathrm{Al}$ dan $\mathrm{Fe}$ dalam larutan sodium silikat. Penelitian ini dilakukan dalam skala laboratorium menggunakan metode batch. Penentuan kondisi optimum meliputi massa adsorben, $\mathrm{pH}$, waktu kontak dan temperatur larutan. Hasil analisis dengan Spektrofotometer Serapan Atom (SSA) menunjukkan efisiensi adsorpsi tertinggi oleh karbon aktif aktivasi $\mathrm{HCl}$ pada larutan sodium silikat mencapai $88,43 \%$ untuk ion $\mathrm{Al}$ dan $41,6 \%$ untuk ion $\mathrm{Fe}$, sedangkan pada karbon aktif aktivasi $\mathrm{H}_{2} \mathrm{SO}_{4} 57,09 \%$ untuk ion $\mathrm{Al}$ dan $35 \%$ untuk ion Fe dan karbon aktif komersil menyerap ion $\mathrm{Al}$ sebesar $87,74 \%$ dan $11,35 \%$ untuk ion $\mathrm{Fe}$.
\end{abstract}

Kata kunci : Adsorpsi, Karbon aktif, Metode batch, SSA.

\begin{abstract}
The research done on the ability of activated carbon as adsorbent to adsorb the ions $\mathrm{Al}$ and $\mathrm{Fe}$ in solution of sodium silicate. This research was conducted in laboratory scale using batch method. Determination of optimum conditions include the mass of adsorbent, $\mathrm{pH}$, contact time and temperature of solution. Results of analysis by Atomic Absorption Spectrofotometer (AAS) showed that highest adsorption efficiency on carbon activated by $\mathrm{HCl}$ in sodium silicate solution reached $88.43 \%$ for the ions $\mathrm{Al}$ and $41.6 \%$ for $\mathrm{Fe}$ ions, where as the carbon activated by $\mathrm{H}_{2} \mathrm{SO}_{4} 57.09 \%$ for the ions $\mathrm{Al}$ and $35 \%$ for the ions $\mathrm{Fe}$ and commercial activated carbon to absorb the ions $\mathrm{Al}$ of $87.74 \%$ and $11.35 \%$ for $\mathrm{Fe}$ ions.
\end{abstract}

Keywords : Adsorption, Activated carbon, batch method, SSA.

\section{PENDAHULUAN}

Indonesia memiliki potensi sumber daya energi terbarukan yang melimpah antara lain energi surya, hal ini karena letak Indonesia yang berada di daerah tropis menerima sinar matahari yang melimpah. Akan tetapi pengembangan energi alternatif ini terbentur dengan mahalnya peralatan panel surya import. Peralatan panel surya tidak dapat diproduksi di dalam negeri karena ketersediaan silikon murni untuk bahan pembuatan panel surya belum mampu dibuat di
Indonesia. Di lain pihak Indonesia memiliki potensi pasir kuarsa yang melimpah, namun pasir kuarsa tersebut tidak dapat dijadikan sebagai bahan baku pembuatan silikon murni untuk panel surya dengan proses pencucian biasa. Untuk itu diperlukan terobosan proses pengolahan pasir kuarsa menjadi silika murni sebagai bahan baku pembuatan logam silikon dengan kemurnian tinggi. Diperlukan paling tidak logam silikon dengan kemurnian 99,999\% sebagai syarat bahan baku untuk panel surya (Stanitski, 2003). 
Pasir kuarsa dari Indonesia meskipun memiliki kemurnian yang tinggi dengan kenampakan kristal yang bagus, ternyata memiliki pengotor dalam bentuk ikatan kristal yang kompleks. Ikatan dalam senyawa kompleks antara kristal silika dengan pengotor, melibatkan pengotor oksida besi, aluminium, titanium, kalsium, magnesium dan lain-lain (Anonim, 2005).

Senyawa kompleks yang berikatan di dalam mineral pasir kuarsa tidak dapat dipisahkan dengan menggunakan proses pemisahan fisik seperti pencucian, flotasi, magnetisasi dan lain-lain. Proses pemisahan secara fisik cenderung hanya memisahkan antara pasir kuarsa dengan pengotor organik yang terdapat dalam pasir kuarsa, sehingga produk hasil pemisahan secara fisik maksimal hanya dihasilkan kristal putih dengan kadar silika maksimal hanya sampai 99\%. Untuk memurnikan pasir kuarsa agar sampai 99,999 $\%$ diperlukan terobosan proses, yaitu dengan memecah ikatan kompleks dalam silika tersebut. Dengan demikian akan diperoleh material silika yang telah bebas dari unsur pengotor untuk memenuhi persyaratan sebagai bahan baku pembuatan panel surya (Angello, 2004).

Pemanfaatan pasir kuarsa dari Indonesia sebagai bahan baku untuk panel surya harus dimulai dari penguasaan teknologi pemurnian silika dari pasir kuarsa, untuk itu perlu adanya penelitian pemurnian silika dari pasir kuarsa dengan terobosan proses. Diharapkan dengan keberhasilan proses ini, akan tumbuh industri pembuatan modul panel surya dari pasir kuarsa Indonesia. Keuntungan lain dengan terkuasainya teknologi tersebut adalah tercukupinya kebutuhan energi yang ramah lingkungan dan sekaligus meningkatkan nilai tambah pasir kuarsa Indonesia.

Pasir kuarsa yang mengandung bahan pengotor tersebut harus dirubah dalam bentuk senyawa yang lebih sederhana dalam larutan berbasis media air. Diperlukan bantuan senyawa alkali dan temperatur yang sangat tinggi yang mampu merubah senyawa kompleks pasir kuarsa menjadi senyawa alkali silikat yang larut dalam air (Juan, 1994).

Senyawa kompleks yang sudah terurai menjadi larutan silikat mengandung ion-ion pengotor $\mathrm{Al}, \mathrm{Fe}, \mathrm{Ti}, \mathrm{Ca}, \mathrm{Mg}$ dan lainlain. Ion pengotor tersebut dapat diambil dengan menggunakan metode ion exchange, pengikatan organik, koagulasi polimer dan adsorpsi menggunakan adsorben karbon aktif, zeolit dan lain-lain.

Karbon aktif digunakan sebagai adsorben karena mempunyai daya adsorpsi selektif, berpori sehingga luas permukaan persatuan massa besar serta mempunyai daya ikat yang kuat terhadap zat yang hendak dipisahkan secara fisik atau kimiawi.

Bahan baku yang dapat dibuat menjadi karbon aktif adalah semua bahan yang mengandung karbon. Bahan-bahan tersebut adalah berbagai jenis kayu, sekam padi, tulang binatang, kulit biji kopi, batu-bara, dan tempurung kelapa. Bila bahan-bahan tersebut dibandingkan, tempurung kelapa merupakan bahan terbaik yang dapat dibuat menjadi karbon aktif karena karbon aktif yang terbuat dari tempurung kelapa memiliki mikropori yang banyak, kadar abu yang rendah, kelarutan dalam air yang tinggi dan reaktivitas yang tinggi (Anonim, 2005). Berdasarkan hal ini maka penelitian dilakukan dengan menggunakan tempurung kelapa sebagai bahan baku.

Pori-pori karbon aktif mempunyai bentuk dan ukuran yang bervariasi dan tidak teratur, ukurannya berkisar antara 10-10000 A. Pori-pori ini dapat menangkap dan menjerap partikel-partikel sangat halus (molekul). Semakin banyaknya zat-zat yang diadsorpsi maka pori-pori ini pada akhirnya akan jenuh sehingga karbon aktif tidak akan berfungsi lagi. Karbon aktif yang telah jenuh dapat direaktifasi kembali, meskipun demikian tidak jarang yang disarankan untuk sekali pakai (Basuki, 2007).

Tujuan dari penelitian ini adalah menentukan kemampuan adsorpsi dari karbon aktif untuk menyerap ion $\mathrm{Al}$ dan $\mathrm{Fe}$ dalam larutan sodium silikat dan mengetahui kondisi optimum dari karbon aktif yang meliputi massa adsorben, $\mathrm{pH}$, waktu kontak, dan temperatur dalam menyerap ion $\mathrm{Al}$ dan $\mathrm{Fe}$.

\section{METODE PENELITIAN}

Tempat dan Waktu Penelitian 
Penelitian ini dilaksanakan selama 4 bulan, April-Juli 2010. Preparasi sampel dan analisis parameter fisik dan kimia serta uji kuantitatif ion logam dilakukan di Laboratorium Metalurgi Ekstraksi, Puslit Metalurgi-LIPI.

\section{Alat dan Bahan}

Spektrofotometer Serapan Atom (SSA) NOVAA 300, Scanning Electron Microscope (SEM) JEOL JSM-6390A, neraca analitik, $\mathrm{pH}$ indikator universal, oven listrik, furnace, crusible, mesin pengayak, mesin penghalus, kertas saring, drum, hotplate, erlenmeyer dan peralatan gelas lainnya.

Bahan yang digunakan dalam penelitian ini adalah pasir kuarsa, $\mathrm{Na}_{2} \mathrm{CO}_{3}, \mathrm{HCl}, \mathrm{H}_{2} \mathrm{SO}_{4}$, $\mathrm{HNO}_{3}$, larutan standar $\mathrm{Al}$ dan $\mathrm{Fe}$, karbon aktif komersil, air demin serta tempurung kelapa (didapatkan dari Pasar Ciputat).

\section{Pelaksanaan Penelitian}

Penelitian dilaksanakan dalam empat tahap. Tahap pertama adalah Roasting pasir kuarsa, kedua pembuatan adsorben dari arang tempurung kelapa, tahap ketiga merupakan tahap aktivasi arang menjadi karbon aktif. Sedangkan tahap keempat adalah pengujian kemampuan penyerapan ion Al dan Fe oleh karbon aktif tersebut dengan variasi massa karbon aktif, $\mathrm{pH}$, waktu kontak, dan temperatur larutan.

\section{Roasting Pasir Kuarsa}

Pasir kuarsa dicuci dengan air bersih sampai hilang kotorannya lalu dikeringkan, setelah itu dicampurkan dengan natrium karbonat dengan berat masingmasing $165 \mathrm{~g}$ pasir dan $135 \mathrm{~g}$ natrium karbonat dan dilakukan proses pencampuran secara merata. Kemudian dimasukkan dalam krusibel lalu dipanaskan sampai temperatur 1100 ${ }^{\circ} \mathrm{C}$, selama dua jam. Lalu lelehan tersebut didinginkan dan digerus menjadi serbuk.

\section{Pembuatan Karbon Aktif dari Tempurung Kelapa}

Tempurung kelapa dimasukkan ke dalam drum/kaleng kemudian dilakukan pembakaran sampai menjadi arang selama 8 jam (Iskandar, 2005). Selanjutnya digrinding/ dihaluskan dengan ukuran 100 mesh, lalu untuk proses aktivasi, arang direndam dalam reagen aktivator $\mathrm{HCl} 4 \mathrm{M}$ dan $\mathrm{H}_{2} \mathrm{SO}_{4} 4$ M selama 24 jam, disaring dan dicuci dengan aquades. Karbon aktif yang dihasilkan kemudian dikeringkan dalam oven pada temperatur $110{ }^{\circ} \mathrm{C}$ selama 3 jam, lalu didinginkan dalam desikator (Purwaningsih, 2000).

\section{Analisis SEM-EDS}

\begin{tabular}{cccl}
\multicolumn{2}{c}{ Pengamatan } & struktur & mikro dan \\
komposisi & kimia & dengan & SEM sebagai
\end{tabular} berikut, sampel karbon aktivasi $\mathrm{HCl}$ dan $\mathrm{H}_{2} \mathrm{SO}_{4}$ yang telah bersih dan kering masingmasing ditempelkan pada pemegang sampel (sample holder) dengan perekat dua muka dilanjutkan dengan pelapisan tipis dengan emas dalam mesin pelapis tipis (sputter). Kemudian dilakukan pengamatan struktur mikro dan komposisi kimianya dengan SEM pada $20 \mathrm{kV}$ dan perbesaran 1400X.

\section{Penentuan Kondisi Optimum Penyerapan Pengaruh Massa Karbon Aktif}

Karbon aktif dengan aktivator $\mathrm{HCl}$ ditimbang dengan berat 0,$1 ; 0,2 ; 0,3 ; 0,4$ dan 0,5 g. Lalu ditambahkan larutan sodium silikat 50 $\mathrm{mL}$ dan diaduk selama 30 menit dengan kecepatan putaran konstan pada temperatur $30{ }^{\circ} \mathrm{C}$. Setelah itu disaring dan filtrat dianalisis dengan SSA.

\section{Pengaruh pH Larutan}

Karbon aktif aktivator $\mathrm{HCl}$ ditimbang dengan berat 0,1 g, lalu dimasukkan dalam Erlenmeyer dan ditambahkan

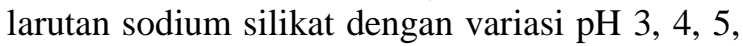
6, dan 7. Kemudian diaduk selama 30 menit dengan kecepatan putaran konstan pada temperatur $30{ }^{\circ} \mathrm{C}$. Setelah itu disaring dan filtrat yang dihasilkan ditampung dan diukur dengan SSA.

\section{Pengaruh Waktu Kontak}

Karbon aktif aktivator $\mathrm{HCl}$ ditimbang dengan berat 0,1 gram, lalu dimasukkan dalam 
Erlenmeyer dan ditambahkan $50 \mathrm{~mL}$ larutan sodium silikat, pada temperatur $30{ }^{\circ} \mathrm{C}$ dan $\mathrm{pH}$ optimum. Kemudian diaduk dengan variasi waktu kontak 15, 30, 45, dan 60 menit, dengan kecepatan putaran konstan.

Setelah itu disaring dan filtrat yang dihasilkan dianalisis dengan SSA.

\section{Pengaruh Temperatur Larutan}

Karbon aktif dengan aktivator $\mathrm{HCl}$ dengan berat $0,1 \mathrm{~g}$, dimasukkan dalam Erlenmeyer dan ditambahkan larutan sodium silikat $50 \mathrm{~mL}$. Kemudian diaduk dengan variasi temperatur 30, 40, 50, 60 dan 70 ${ }^{\circ} \mathrm{C}$, pada $\mathrm{pH}$ optimum dan waktu optimum dengan kecepatan putaran konstan. Setelah itu disaring dan filtrat yang dihasilkan ditampung untuk dianalisis dengan SSA.

\section{Perbandingan Aktivasi Karbon Aktif Antara Aktivator $\mathrm{HCl}, \mathrm{H}_{2} \mathrm{SO}_{4}$ dan Komersil}

Karbon aktif dengan aktivator $\mathrm{HCl}$, $\mathrm{H}_{2} \mathrm{SO}_{4}$ dan komersil masing-masing ditimbang dengan berat $0,1 \mathrm{~g}$, lalu dimasukkan dalam Erlenmeyer dan ditambahkan $50 \mathrm{~mL}$ larutan sodium silikat, pada temperatur 30 ${ }^{\circ} \mathrm{C}, \mathrm{pH}$ optimum, kemudian diaduk 30 menit dengan kecepatan putaran konstan. Setelah itu disaring dan filtrat yang dihasilkan dianalisis dengan SSA.

\section{HASIL DAN PEMBAHASAN}

\section{Pembuatan Karbon Aktif}

Karbon aktif yang dibuat berasal dari tempurung kelapa yang telah dibersihkan dan dikeringkan untuk mengurangi kadar air. Selanjutnya, tempurung kelapa tersebut dimasukkan ke dalam drum/kaleng yang telah dilubangi sebelumnya agar oksigen dapat masuk sehingga proses pembakaran dapat berlangsung dengan baik. Setelah terbentuk arang atau karbon, proses selanjutnya adalah menghaluskan arang tersebut menjadi ukuran 100 mesh, hal ini dilakukan agar proses penyerapan adsorben terhadap adsorbat lebih cepat karena secara teoritis semakin kecil ukuran partikel, maka luas permukaan adsorben akan bertambah luas, sehingga ion logam akan lebih mudah terserap pada permukaan adsorben (Sunarya, 2006).

Untuk proses aktivasi kimia digunakan $\mathrm{HCl}$, sedangkan untuk pembanding digunakan $\mathrm{H}_{2} \mathrm{SO}_{4}$ dan karbon aktif komersil yang ada di pasaran. Aktivasi bertujuan untuk memperluas volume rongga atau pori karbon aktif karena molekul-molekul pengaktif akan teradsorpsi oleh bahan karbon yang akan melarutkan pengotorpengotor yang berada dalam pori karbon seperti mineral-mineral anorganik (Miftah dkk, 2006).

\section{Karakterisasi Permukaan Adsorben Melalui Analisis Scanning Electron Microscope (SEM)}

Morfologi permukaan adsorben karbon aktif aktivasi $\mathrm{HCl}$ dan aktivasi $\mathrm{H}_{2} \mathrm{SO}_{4}$ diidentifikasi menggunakan SEM-EDS dengan perbesaran objek $1,4 \times 10^{3}$ (1400 kali) yang hasilnya dapat dilihat pada Gambar 1 berikut :

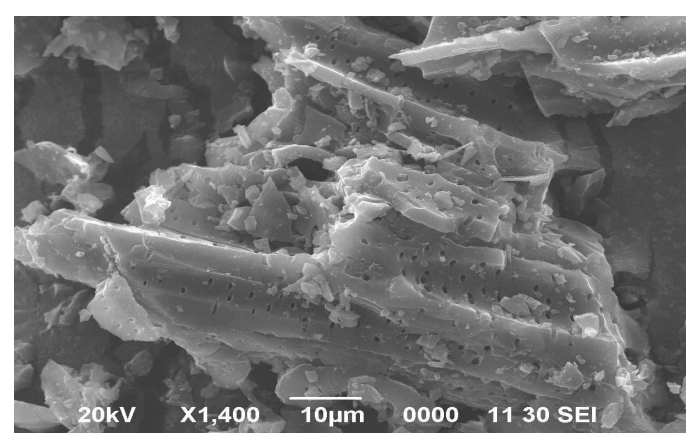

a. $\mathrm{KA}$ aktivasi $\mathrm{HCl}$

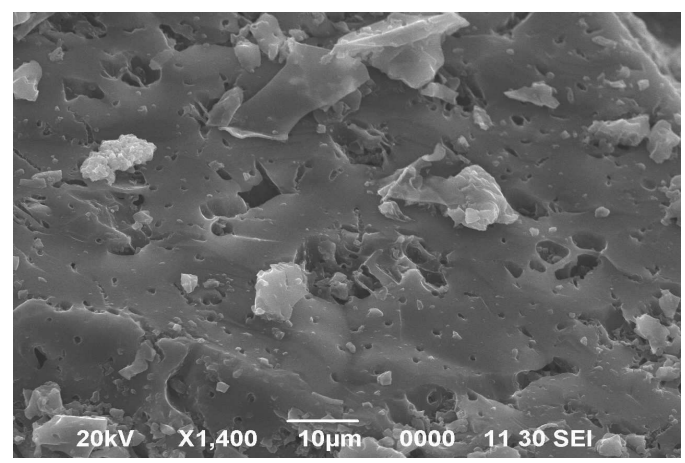

b. KA aktivasi $\mathrm{H}_{2} \mathrm{SO}_{4}$

Gambar 1. Mikrograf SEM permukaan adsorben 
Berdasarkan Gambar 1, terlihat perbedaan morfologi permukaan dari karbon aktif aktivasi $\mathrm{HCl}$ dan karbon aktif aktivasi $\mathrm{H}_{2} \mathrm{SO}_{4}$. Pada karbon aktif aktivasi $\mathrm{HCl}$ terlihat distribusi pori-pori yang lebih beraturan dengan jumlah pori yang lebih banyak dibanding $\mathrm{H}_{2} \mathrm{SO}_{4}$. Selain itu, pada karbon aktif aktivasi $\mathrm{HCl}$ jumlah pori-pori permukaan terlihat lebih banyak dibandingkan dengan pori-pori karbon aktif aktivasi $\mathrm{H}_{2} \mathrm{SO}_{4}$ yang lebih sedikit. Hal ini dikarenakan aktivasi dengan $\mathrm{HCl}$ lebih dapat melarutkan pengotor sehingga pori-pori lebih banyak terbentuk dan proses penjerapan adsorbat menjadi lebih maksimal, dibandingkan dengan aktivasi $\mathrm{H}_{2} \mathrm{SO}_{4}$ yang lebih sedikit jumlah poriporinya.

Berdasarkan hasil karakterisasi EDS yang dilakukan, diperoleh informasi bahwa pada permukaan karbon aktif aktivasi $\mathrm{HCl}$ sebelum adsorpsi terdapat beberapa unsur kimia, yaitu karbon $84,43 \%$, oksigen $10,16 \%$, klorida $10,16 \%$ dan tembaga $1,34 \%$. Sedangkan pada aktivasi $\mathrm{H}_{2} \mathrm{SO}_{4}$, yaitu karbon $69,57 \%$, oksigen $26,68 \%$, dan sulfur $3,75 \%$. Hasil tersebut menunjukkan bahwa komposisi karbon pada aktivasi $\mathrm{HCl}$ lebih banyak dibandingkan dengan aktivasi $\mathrm{H}_{2} \mathrm{SO}_{4}$. Namun, kadar karbon kedua hasil aktivasi tersebut masih memenuhi syarat standar mutu yaitu minimum 65\% (SNI, 1995).

\section{Penentuan Kemampuan Adsorpsi Ion Al dan Fe Oleh Karbon Aktif Aktivasi HCl}

\section{Pengaruh Massa Adsorben}

Pengaruh massa adsorben pada penelitian ini ditentukan dengan variasi massa 0,$1 ; 0,2 ; 0,3 ; 0,4 ;$ dan $0,5 \mathrm{~g}$, dengan volume 50 $\mathrm{mL}, \mathrm{pH} 3$, temperatur proses $30^{\circ} \mathrm{C}$ dan waktu 30 menit. Berdasarkan hasil penelitian ini, massa adsorben $0,5 \mathrm{~g}$ memiliki nilai efisiensi adsorpsi yang tinggi, yaitu $65,85 \%$ untuk penyerapan ion Al. Hasil yang sama juga didapat pada penyerapan ion $\mathrm{Fe}$, dimana penyerapan pada 0,5 $\mathrm{g}$ dengan nilai efisiensi adsorpsinya sebesar $32,16 \%$. Grafik hubungan antara efisiensi adsorpsi dengan massa adsorben untuk penyerapan ion $\mathrm{Al}$ dan $\mathrm{Fe}$ oleh karbon aktif dapat dilihat pada Gambar 2.

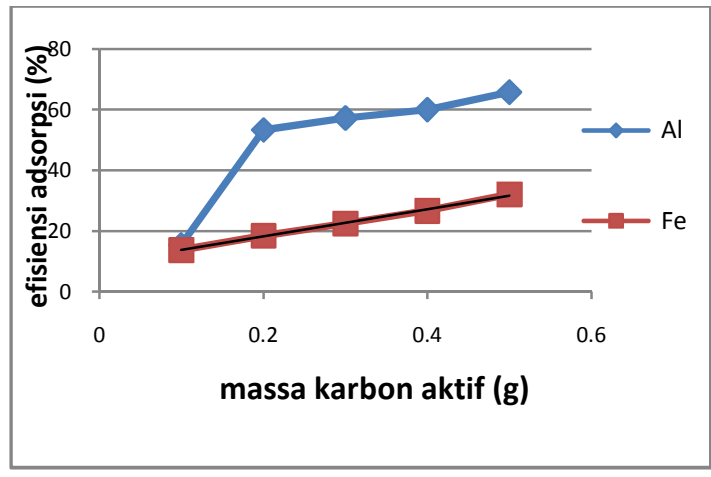

Gambar 2. Pengaruh massa karbon aktif terhadap ion $\mathrm{Al}$ dan $\mathrm{Fe}$

Semakin bertambah massa karbon aktif yang digunakan, maka nilai efisiensi adsorpsinya terhadap ion semakin tinggi. Bertambahnya massa karbon aktif sebanding dengan bertambahnya jumlah partikel dan luas permukaan karbon aktif sehingga menyebabkan jumlah tempat mengikat ion logam bertambah dan efisiensi adsorpsinya pun meningkat (Messayu, 2009).

Dari hasil penelitian tentang pengaruh massa karbon aktif ini juga menunjukkan nilai kapasitas adsorpsi yang semakin menurun dengan bertambahnya massa adsorben. Hal ini dikarenakan pada saat ada peningkatan massa adsorben, maka ada peningkatan presentase nilai efisiensi adsorpsi dan penurunan kapasitas adsorpsi (Barros, 2003).

Menurut Wijayanti (2009), bila permukaan sudah jenuh atau mendekati jenuh terhadap adsorbat, dapat terjadi dua hal, yaitu pertama terbentuk lapisan adsorpsi kedua dan seterusnya di atas adsorbat yang telah terikat di permukaan, gejala ini disebut adsorpsi multilayer, sedangkan yang kedua tidak terbentuk lapisan kedua dan seterusnya sehingga adsorbat yang belum teradsorpsi berdifusi keluar pori dan kembali ke arus fluida.

\section{Pengaruh pH Larutan}

$\mathrm{pH}$ larutan mempunyai pengaruh dalam proses adsorpsi, karena $\mathrm{pH}$ akan mempengaruhi muatan permukaan adsorben (Riapanitra, dkk, 2006). Pada penelitian ini dilakukan penentuan $\mathrm{pH}$ optimum oleh karbon aktif dengan variasi $\mathrm{pH}$ yang digunakan adalah 3, 4, 5, 6 dan 7, dengan 
volume $50 \mathrm{~mL}$, massa $0.1 \mathrm{~g}$, temperatur proses $30{ }^{\circ} \mathrm{C}$ dan waktu 30 menit. Berdasarkan hasil penelitian ini, $\mathrm{pH}$ optimum untuk penyerapan ion Al terjadi pada kondisi $\mathrm{pH} 5$ dengan nilai efisiensi adsorpsi sebesar 68,64 \%, kurva hubungannya dapat dilihat pada Gambar 3 di bawah ini :

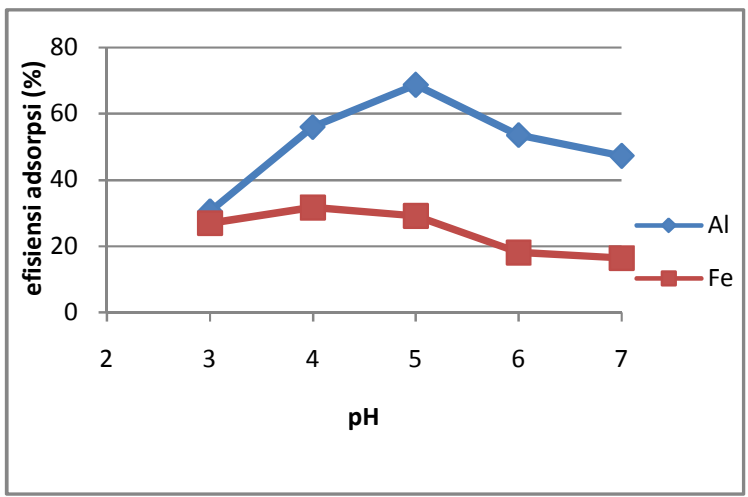

Gambar 3. Pengaruh $\mathrm{pH}$ larutan sampel terhadap efisiensi adsorpsi ion $\mathrm{Al}$ dan $\mathrm{Fe}$ oleh karbon aktif

Sedangkan untuk penyerapan ion $\mathrm{Fe}, \mathrm{pH}$ optimum terjadi pada $\mathrm{pH} 4$ dengan nilai efisiensi adsorpsi sebesar 31,68\%.

Pada kondisi $\mathrm{pH}$ asam proses penyerapan semua ion rendah. Hal ini karena permukaan adsorben pada $\mathrm{pH}$ rendah dikelilingi oleh ion $\mathrm{H}^{+}$, dimana akan terjadi tolakan antara permukaan adsorben dengan ion logam, sehingga adsorpsinya pun menjadi rendah (Sembiring, 2009).

Pada $\mathrm{pH}$ netral atau cenderung basa efisiensi juga menurun. Hal ini disebabkan karena pada $\mathrm{pH}$ netral ion logam dapat mengalami reaksi hidrolisis dalam larutan sehingga tidak stabil dan menyebabkan kemampuan karbon aktif untuk menyerap ion tersebut menurun. Sedangkan pada kondisi basa atau $\mathrm{pH}$ basa, ion logam dapat membentuk endapan hidroksida sehingga proses adsorpsi sulit terjadi (Nurhasni, 2002; Refilda, dkk., 2001; Utomo et al., 2006)

\section{Pengaruh Waktu Kontak}

Pengaruh waktu kontak dalam penelitian ini ditentukan dengan variasi waktu 5, 15, 30, 45, dan 60 menit, dengan volume $50 \mathrm{~mL}$, massa karbon aktif $0.1 \mathrm{~g}$, temperatur proses $30{ }^{\circ} \mathrm{C}$ dan
pH 5 untuk Al dan pH 4 untuk Fe. Dari hasil ini didapatkan waktu kontak yang maksimum untuk terjadinya adsorpsi adalah 60 menit dengan nilai efisiensi adsorpsinya sebesar 78,92\% untuk ion Al dan $31,75 \%$ untuk ion Fe. Kurva hubungan antara efisiensi adsorpsi dengan waktu kontak adsorpsi dapat dilihat pada Gambar 4 di bawah ini.

Peningkatan adsorpsi yang tajam terlihat pada waktu kontak antara 30 menit sampai 60 menit. Besarnya kenaikan penyerapan ion $\mathrm{Al}$ yaitu dari $44.15 \%$ menjadi $78,92 \%$, sedangkan ion $\mathrm{Fe}$ dari $26.47 \%$ menjadi $31,75 \%$. Hal tersebut juga menunjukkan bahwa waktu kontak optimum yaitu waktu disaat adsorben mampu menyerap adsorbat secara maksimal adalah interaksi selama 60 menit.

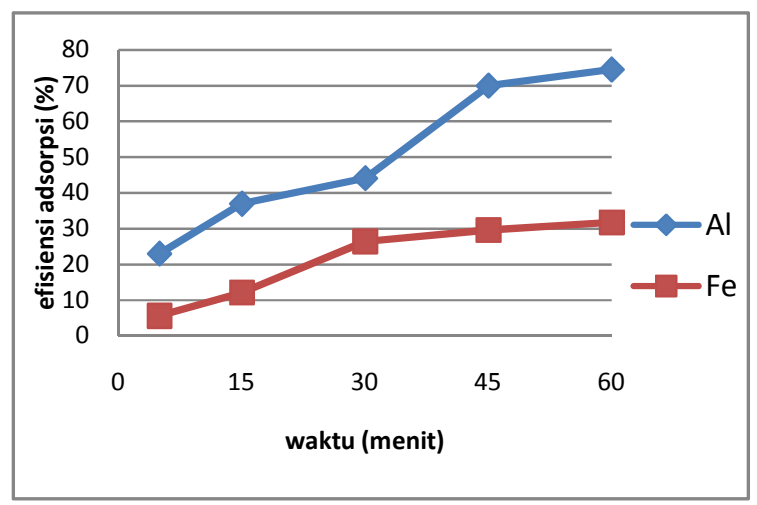

Gambar 4. Pengaruh waktu kontak terhadap efisiensi adsorpsi ion $\mathrm{Al}$ dan $\mathrm{Fe}$ oleh karbon aktif

Dalam Gambar juga terlihat waktu kontak yang relatif singkat dapat menyebabkan proses adsorpsi belum optimal hal ini disebabkan karena kelajuan adsorpsi ditentukan oleh laju difusi spesies adsorbat pada padatan adsorben. Selain itu sisi aktif karbon akan semakin banyak terisi oleh kedua ion tersebut dengan semakin lamanya waktu adsorpsi, karena semakin lama waktu adsorpsi maka frekuensi tumbukan diantara partikel adsorbat dengan adsorben semakin besar pula (Indrawati, 2009).

\section{Pengaruh Temperatur larutan}

Pengaruh temperatur larutan ditentukan dengan variasi temperatur 30, 40, 50, 60 dan 70 ${ }^{0} \mathrm{C}$, dengan volume $50 \mathrm{~mL}$, massa karbon aktif $0.1 \mathrm{~g}$, pH 5 untuk $\mathrm{Al}$ dan $\mathrm{pH} 4$ untuk Fe dan 
waktu kontak 30 menit. Dari hasil penelitian didapat temperatur yang terbaik pada $30{ }^{\circ} \mathrm{C}$ atau temperatur ruang untuk penyerapan ion logam Al yaitu sebesar $88,43 \%$. Kurva hubungan antara efisiensi adsorpsi dengan temperatur larutan dapat dilihat pada Gambar 5 di bawah ini :

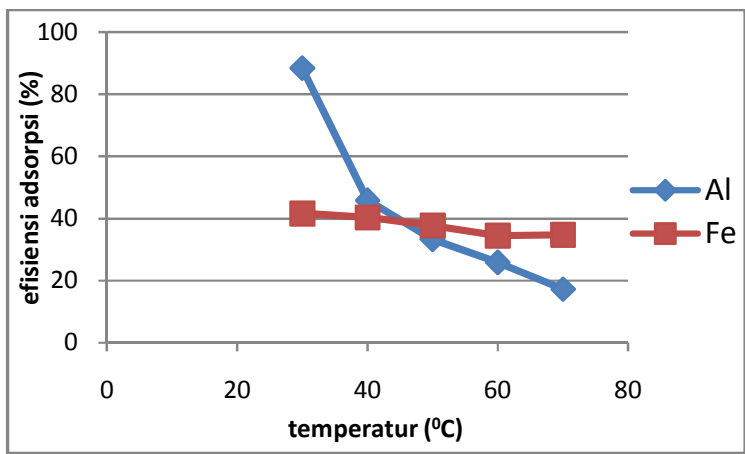

Gambar 5. Pengaruh temperatur larutan sampel terhadap efisiensi adsorpsi ion $\mathrm{Al}$ dan $\mathrm{Fe}$ oleh karbon aktif

Hal ini juga sama dengan penyerapan ion $\mathrm{Fe}$, dimana temperatur yang terbaiknya juga $30{ }^{\circ} \mathrm{C}$, dengan nilai efisiensi adsorpsinya sebesar $41,6 \%$. Penurunan efisiensi adsorpsi seiring dengan kenaikan temperatur, semakin tinggi temperatur maka semakin kecil juga kapasitas adsorpsi maksimumnya, karena pada adsorpsi fisik, temperatur yang semakin tinggi pergerakan ion logam semakin cepat sehingga jumlah ion yang terserap oleh adsorben semakin berkurang, selain itu juga kenaikan temperatur menyebabkan desorpsi semakin besar (Do, 1988 dan Susantiani, 2009). Hal lain kenaikkan temperatur pada $\mathrm{pH}$ larutan yang cenderung basa, dapat meningkatkan proses hidrolisa sehingga ion logamnya mengendap.

\section{Isoterm Adsorpsi}

Untuk mempelajari mekanisme adsorpsi dapat digunakan beberapa tipe isoterm adsorpsi, seperti isoterm Langmuir dan isoterm Freundlich. Untuk zat cair, konsentrasi dinyatakan dalam satuan massa, seperti bagian per sejuta (part per million, ppm). Konsentrasi adsorbat pada zat padat dinyatakan sebagai massa yang teradsorpsi per satuan massa adsorben semula. Isoterm adsorpsi menguraikan bagaimana adsorbat saling berhubungan dengan adsorben dan dalam optimisasi penggunaan adsorben.

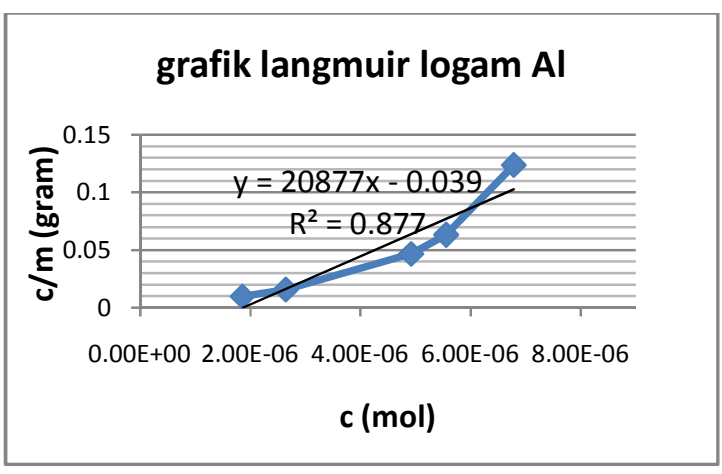

(a)

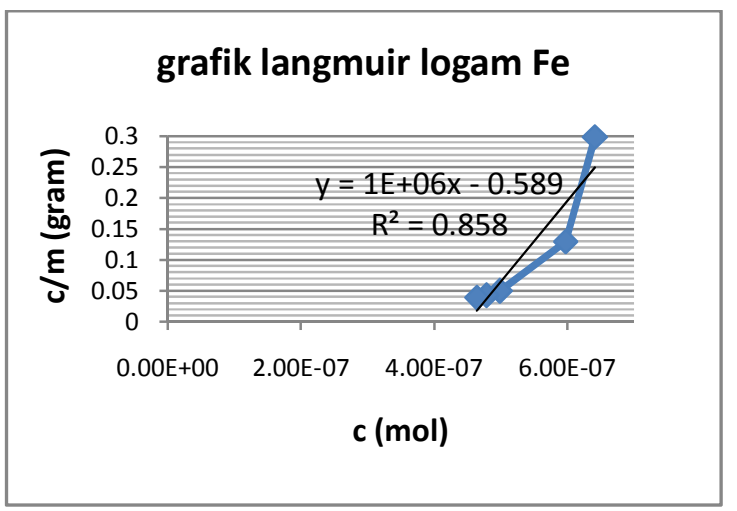

(b)

Gambar 6. Grafik isoterm Langmuir adsorpsi ion $\mathrm{Al}$ (a) dan ion $\mathrm{Fe}$ (b) oleh karbon aktif

Gambar 6 di atas menunjukkan grafik isoterm Langmuir untuk kedua ion $\mathrm{Al}$ dan $\mathrm{Fe}$. Dari grafik isoterm tersebut, dapat dilihat bahwa nilai koefisien korelasi $\left(\mathrm{R}^{2}\right)$ dari persamaan kesetimbangan adsorpsi Langmuir adalah 0.877 untuk ion logam $\mathrm{Al}$ dan 0,858 untuk ion $\mathrm{Fe}$.

Sedangkan untuk grafik isotherm Freundlich dapat dilihat pada Gambar 7 di atas, didapatkan nilai $\mathrm{R}^{2}$ untuk adsorpsi ion $\mathrm{Al}$ adalah 0,903 dan 0,955 untuk ion Fe. Nilai $R^{2}$ yang mendekati 1 ini menunjukkan bahwa proses adsorpsi yang terjadi pada penyerapan ion $\mathrm{Al}$ dan Fe cenderung bersifat fisisorpsi. Pada proses adsorpsi fisik, terjadi interaksi gaya Van der walls antara adsorbat dan adsorben yang lemah dan umumnya terjadi pada temperatur rendah sehingga bertambahnya temperatur menyebabkan adsorpsi yang terjadi berkurang 
dengan mencolok (Castellan, 1971). Hal ini dapat dilihat pada variasi temperatur, dimana efisiensi adsorpsinya terus berkurang seiring bertambahnya kenaikan temperatur larutan.

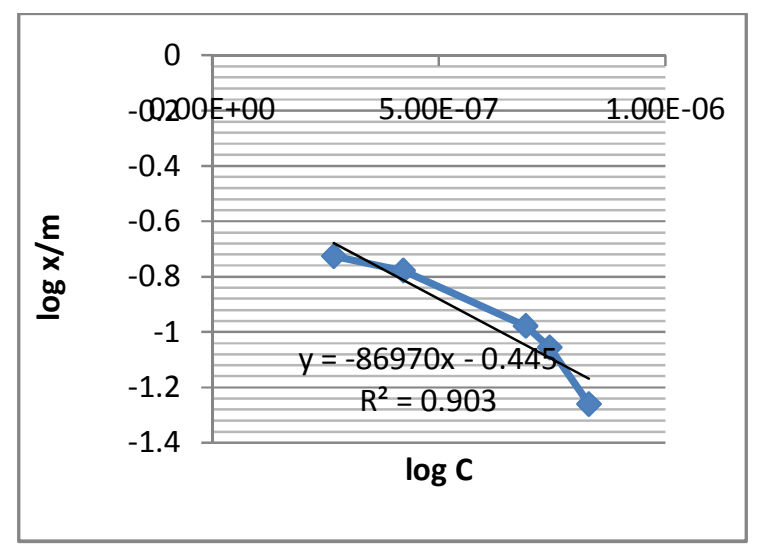

(a)

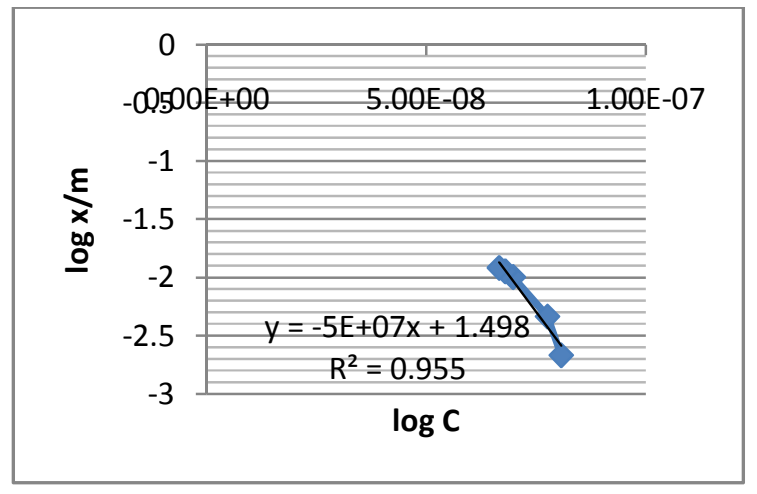

(b)

Gambar 7. Grafik isoterm Freundlich adsorpsi ion $\mathrm{Al}$ (a) dan ion $\mathrm{Fe}$ (b) oleh karbon aktif

Energi adsorpsi untuk masing-masing ion tersebut adalah sebesar 3,2899 KJ/mol untuk ion Al dan 3,5779 $\mathrm{KJ} / \mathrm{mol}$ untuk ion Fe. Data yang digunakan untuk perhitungan kemampuan adsorpsi maksimum, konstanta kesetimbangan, dan energi adsorpsi adalah data yang diperoleh saat percobaan variasi waktu. Data tersebut dibuat berdasarkan persamaan langmuir, diperoleh konstanta kesetimbangan yang digunakan untuk menghitung energi adsorpsi.

\section{Perbandingan Aktivasi Karbon Aktif antara $\mathrm{HCl}, \mathrm{H}_{2} \mathrm{SO}_{4}$ dan Komersil}

Hasil penyerapan ion $\mathrm{Al}$ dan $\mathrm{Fe}$ oleh karbon aktif aktivasi $\mathrm{HCl}$ lebih baik jika dibandingkan dengan adsorpsi karbon aktif menggunakan aktivasi $\mathrm{H}_{2} \mathrm{SO}_{4}$ dan komersil.

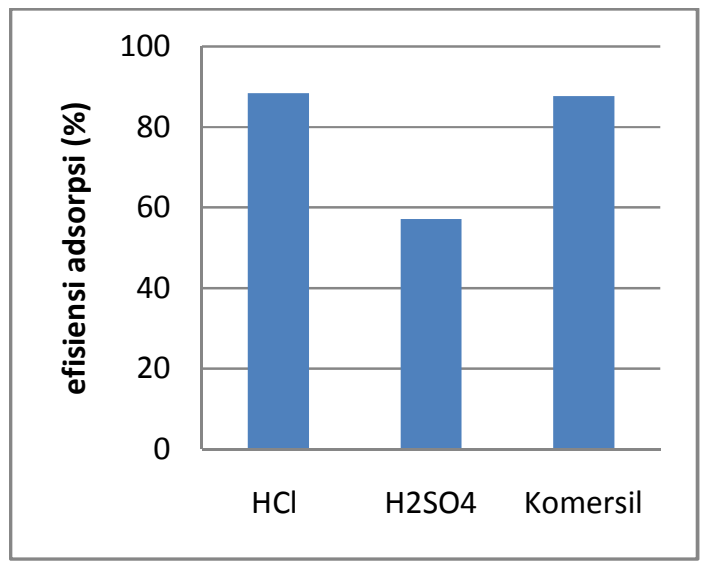

Gambar 8. Perbandingan adsorpsi ion $\mathrm{Al}$

Hasil penyerapan aktivasi $\mathrm{HCl}$ untuk ion Al sebesar 88,43 \% dan 41,6 \% untuk ion Fe. Karbon aktif aktivasi $\mathrm{H}_{2} \mathrm{SO}_{4} 57,09 \%$ untuk ion $\mathrm{Al}$ dan $35 \%$ untuk ion $\mathrm{Fe}$, sedangkan untuk komersil menyerap ion $\mathrm{Al}$ sebesar 87,74\% dan $11,35 \%$ untuk ion Fe.

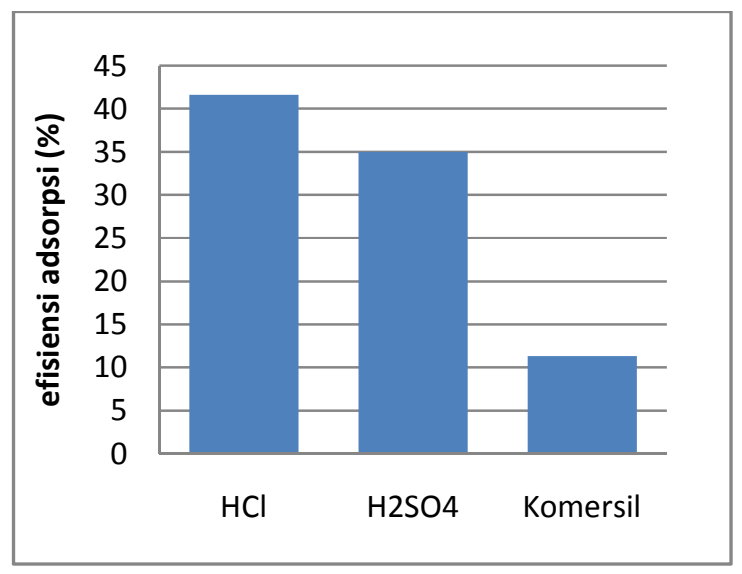

Gambar 9. Perbandingan adsorpsi ion $\mathrm{Fe}$

Kecilnya daya adsorpsi karbon aktif yang diaktivasi dengan $\mathrm{H}_{2} \mathrm{SO}_{4}$ dibandingkan aktivasi $\mathrm{HCl}$ terhadap penyerapan ion, dapat disebabkan rusaknya dinding struktur dari karbon tersebut oleh $\mathrm{H}_{2} \mathrm{SO}_{4}$ yang bersifat 
dekstruktif, hal ini dapat di lihat pada hasil analisa EDS, kadar karbon aktif aktivasi $\mathrm{H}_{2} \mathrm{SO}_{4}$ yaitu hanya $69,57 \%$ lebih sedikit jika dibandingkan dengan aktivasi $\mathrm{HCl}$ kadar karbonnya $84,43 \%$. Hal tersebut akan berakibat pada daya adsorpsi terhadap ion logam semakin kecil (Lua dan Yang, 2004).

Hal ini menunjukkan bahwa perbedaan aktivator dalam aktivasi kimia pada karbon aktif, berpengaruh cukup besar terhadap kemampuan penyerapan ion-ion. Hal ini disebabkan penggunaan aktivator yang berbeda akan menghasilkan struktur pori yang berbeda (Yang, 2003). Sedangkan pada karbon aktif komersil penyerapan untuk ion $\mathrm{Al}$ cukup tinggi, tetapi untuk ion $\mathrm{Fe}$ rendah sehingga karbon aktif komersil ini lebih efektif untuk penyerapan ion Al karena karbon aktif komersil mempunyai sifat-sifat yang sangat bervariasi yang tergantung pada aplikasinya. Namun, dalam penelitian ini karbon aktif komersil yang digunakan merupakan karbon aktif yang berada di Pasaran, yang spesifikasinya tidak diketahui sehingga sulit untuk menjelaskan faktor yang mempengaruhinya dalam proses penyerapan yang terjadi.

\section{KESIMPULAN DAN SARAN}

\section{Kesimpulan}

Dari hasil penelitian yang telah dilakukan dapat disimpulkan sebagai berikut :

1. Karbon aktif dapat digunakan sebagai adsorben dengan nilai efisiensi adsorpsi mencapai $88,43 \%$ dan $41,6 \%$ untuk masingmasing ion logam $\mathrm{Al}$ dan ion logam $\mathrm{Fe}$.

2. Kondisi optimum adsorpsi oleh karbon aktif untuk ion logam $\mathrm{Al}$ dan $\mathrm{Fe}$ dengan parameter $\mathrm{pH} 5$ untuk $\mathrm{Al}$ dan $\mathrm{pH} 4$ untuk $\mathrm{Fe}$, waktu kontak 60 menit untuk $\mathrm{Al}$ dan $\mathrm{Fe}$, serta $30{ }^{\circ} \mathrm{C}$ untuk $\mathrm{Al}$ dan $\mathrm{Fe}$ pada variasi temperatur larutan.

3. Nilai kapasitas adsorpsi untuk masingmasing ion logam $\mathrm{Al}$ dan $\mathrm{Fe}$ adalah sebesar $1,0262 \mathrm{mg} / \mathrm{g}$ dan $0,2473 \mathrm{mg} / \mathrm{g}$.

\section{Saran}

Perlu dilakukan penelitian lebih lanjut mengenai parameter lain yang berpengaruh terhadap efisiensi adsoprsi. Selain itu, perlu dilakukan analisis lebih lanjut terhadap berbagai jenis ion logam lainnya yang terdapat pada larutan sodium silikat tersebut.

\section{DAFTAR PUSTAKA}

1. Angello, VN. 2004. The Silica Industry in the Republic of South Africa. Republic of South Africa: Department of Minerals and Energy.

2. Anonim. 2005. Activated Carbon 101. www.carbochem.com.

3. Atkins, P. W. 1999. Kimia Fisika (Alih bahasa: Dra. Irma I. K). Jakarta: Erlangga

4. Barros, L.M., Maedo, G.R., Duarte, M.M.L., Silva, E.P., and Lobato.2003. Biosorption Cadmium Using the Fungus Aspergilus niger. Braz J. Chem. (20): 1-17

5. Basuki, Kris Tri. 2007. Penurunan Konsentrasi $\mathrm{CO}$ dan $\mathrm{NO}_{2}$ Pada Emisi Gas Buang Dengan Menggunakan Media Penyisipan $\mathrm{TiO}_{2}$ Lokal Pada Karbon Aktif. JFN, Vol.1 No.1

6. Castellan. 1971.Physical Chemistry. Edisi kedua. Amsterdam: Addison Wesley Publising Company.

7. Do, D.D., 1998, "Adsorption Analysis: Equillibra and Kinetics ", vol 1, Imperial Collegs Press, London

8. Indrawati, Lina. 2009. Aktivasi Abu Layang Batubara dan Aplkasinya Pada Proses Adsorpsi Ion Logam $\mathrm{Cr}$ dalam Limbah Elektroplating.Tugas Akhir II. Semarang: Universitas Negeri Semarang.

9. Iskandar, Haris. 2005. Cara Pembuatan Arang Kayu. Bogor: PT. Inti Prima Karya.

10. Juan-Lauro, Aguirre, 1994. Process for Purifying Silica Sand. New York: United States Patent.

11. Lua, A.C, dan Yang, T., 2004. Effect of Activated Temperature on The Textural and Chemical Properties of Potassium Hydroxide Activated Carbon Prepared from Pistachio-Nut Shell. J. Coll. Interf. Sc. 274: 594-601.

12. Messayu, Paramitha. 2009. Limbah Arang Sekam Padi Sebagai Adsorben Ion Cr (III) dan Cr (IV). Skripsi. Bogor : Institut Pertanian Bogor.

13. Miftah, Dkk. 2006. Pengaruh Aktivator Pada Karbon Aktif Tempurung Kelapa Untuk Adsorpsi Logam Berat $\mathrm{Pb}$ (II). Semarang: Universitas Diponegoro. 
14. Nurhasni. 2002. Penggunaan Genjer (Limnocharis Flava) Untuk Menyerap Ion Kadmium, Kromium, dan Tembaga Dalam Air Limbah. Tesis. Padang: Universitas Andalas.

15. Purwaningsih. 2000. Pemanfaatan Arang Aktif Cangkang Kelapa Sawit Sebagai Adsorben Pada Limbah Cair Kayu Lapis. Skripsi. Samarinda: Universitas Mulawarman.

16. Refilda., Rahmania Zein., Rahmayeni. 2001. Pemanfaatan Ampas Tebu Sebagai Bahan Alternatif Pengganti Penyerap Sintetik Logamlogam Berat Pada Air Limbah. Skripsi. Padang: Universitas Andalas.

17. Riapanitra, Anung,T. Setyaningtyas dan K. Riyani. 2006. Penentuan Waktu Kontak dan pH Optimum Penyerapan Metilen Biru Menggunakan Abu Sekam Padi. J. Molekul. 1(1): 41-44.

18. Sembiring, Meilita Tryana; Tuti Sarma Sinaga. 2003. Arang Aktif, Pengenalan dan Proses Pembuatannya. Medan : Universitas Sumatra Utara.

19. Standar Nasional Indonesia. 1995. SNI 06-3730-1995: Arang Aktif Teknis. Jakarta: Dewan Standarisasi Nasional.

20. Stanitski, Conrad L. 2003. Chemistry in Context : Applying Chemistry to Society-4th ed. New York : Mc Graw-Hill.

21. Sunarya, Asri Ismayati. Biosorpsi Cd (II) dan $\mathrm{Pb}$ (II) Menggunakan Kulit Jeruk Siam (Citrus reticulata). Skripsi. Bogor: Institut Pertanian Bogor.

22. Susantiani, Evi. 2009. Pengaruh Temperatur Larutan terhadap Adsorpsi Ion $\mathrm{Cd}^{2+}$ dengan CoIon $\mathrm{Cu}^{2+}$ dalam Berbagai Konsentrasi oleh Arang Sekam Padi dengan Metode Batch. Skripsi. Malang: Universitas Negeri Malang.

23. Anonim. 2005. Informasi Mineral dan Batubara : Pasir kwarsa. www.tekmira.esdm.go.id.

24. Wijayanti, Ria. 2009. Arang Aktif dari Ampas Tebu Sebagai Adsorben Pada Pemurnian Minyak Goreng Bekas. Skripsi. Bogor: Institut Pertanian Bogor

25. Yang, R.T. 2003. Adsorbent: Fundamentals and Aplplcation. New York: John Wiley \& Sons. 